\title{
Effects of returning organic waste on soil enzymes and microbial quantity in dryland farming**
}

\author{
Ling Sun ${ }^{1}$, Zhixu Sun ${ }^{2}$, Yaa Opoku-Kwanowaa ${ }^{1}$ (1) Juan $\mathrm{Hu}^{3}$, and Jinggui $W u^{1 *}$ \\ ${ }^{1}$ College of Resource and Environmental Science, Jilin Agricultural University, Changchun, 130118, China \\ ${ }^{2}$ Jilin Province Soil Fertilizer Station, Changchun, 130033, China \\ ${ }^{3}$ Jilin Provincial Laboratory of Grassland Farming, Northeast Institute of Geography and Agroecology Chinese Academy of Sciences, \\ Changchun, China
}

Received April 21, 2021; accepted September 17, 2021

\begin{abstract}
The application of animal manure combined with straw is an important strategy for sustainable agricultural production. The objective of this study was to investigate the effects of animal manure combined with straw on soil enzymes and microbial quantity. The two-year experiment involved four treatments: maize straw only, maize straw plus ox manure, maize straw plus chicken manure, and maize straw plus pig manure. In 2018 and 2019, treatments with animal manure combined with straw led to increased levels of soil microbial quantity, soil enzyme activity, and yields. Compared to other treatments, higher catalase activities were achieved in both years for the maize straw plus ox manure and maize straw plus pig manure treatments whereas the cellulase activities were higher for the maize straw plus ox manure and maize straw plus chicken manure treatments. The maize straw plus ox manure treatment had the highest number of soil bacteria, and the quantity of actinomycetes was higher after the applications of maize straw plus ox manure and maize straw plus chicken manure as compared to the other treatments. Moreover, compared to the application of maize straw only, treatment maize straw plus pig manure had the most significant effect on the soil urease activity, invertase activity, fungal quantity, and maize yield with 43.9, $35.9,52.0$, and $31.7 \%$ increases, respectively. In conclusion, our findings suggested that animal manure combined with straw, especially the application of maize straw plus pig manure was the most effective treatment for enhancing soil enzymes and microbial quantity and also promoting maize yield.

Keywords: animal manure, maize straw, enzyme activities, microbial quantity
\end{abstract}

*Corresponding author e-mail: wujinggui@jlau.edu.cn

**This research was supported by the Research Foundation of the Science \& Technology Agency of Jilin Province, China (20190301018NY; 2019-2021), and the National Key Research and Development Program of China (2018YFD0300203; 2018-2020, 2017YFD0201801; 2017-2020).

\section{INTRODUCTION}

Corn straw and animal manure are high-quality organic materials which contain a large amount of organic matter as well as nitrogen $(\mathrm{N})$, phosphorus $(\mathrm{P})$, and other trace elements necessary for plant growth and agricultural sustainability (Kumar et al., 2018). Statistical data have shown that every year, about 700 million tonnes of crop straw and 3.8 billion tonnes of animal manure are produced as agricultural waste in China (Wang et al., 2017; Wang et al., 2020). The burning of straw and the inappropriate disposal of animal manure leads to a waste of resources and environmental pollution ( $\mathrm{Ji}, 2015)$. Returning straw to the field is an effective practice that facilitates the management of agricultural residues (Blumfield et al., 2003). Hou et al. (2012) reported that the application of straw mulch is a traditional agricultural practice used to reduce evaporation and improve crop yields, however, the traditional ways of applying mulch do have some shortcomings, such as the slow decomposition rate of the straw which leads to a low emergence rate for seedlings (Hu et al., 2016). Lafond et al. (2009) found that straw mulch had no significant effects on crop production and soil quality. Therefore, this research seeks to test a new method of returning straw, which may serve to alleviate the shortcomings of the traditional straws techniques in order to improve sustainable agricultural production.

(C) 2021 Institute of Agrophysics, Polish Academy of Sciences (c) (1) (3) $\Theta$ 
Soil enzymes are involved in the biogeochemical cycle of most nutrient elements, the decomposition and synthesis of humus, and the transformation of organic compounds (Benavente et al., 2018). They play an important catalytic role in ecosystem metabolism, which is not only an important index of soil fertility but also one of the most important indicators of soil metabolism (Dominik et al., 2018; Gajda et al., 2013). Previous studies have illustrated that the application of $\mathrm{N}$ fertilizer, as well as returning straw to the soil can be used to promote enzyme activities (Zhao et al., 2016; Jian et al., 2016). Some studies have also shown that organic fertilizer is more efficient at stimulating soil enzymes, while inorganic fertilizers had a weaker effect on soil enzyme activities (Yu et al., 2012; Zhang et al., 2015). In terrestrial ecosystems, soil microorganisms play important roles in the biogeochemical cycling of soil nutrients and the decomposition of organic matter (Cusack et al., 2011; Mierzwa-Hersztek et al., 2019). The number of soil bacteria, fungi, and actinomycetes can be used to determine the total distribution of soil microorganisms and the decomposition and transformation of organic matter (Zimmerman, 2010). Soil urease activity is an important factor in the evaluation of the soil $\mathrm{N}$ status (Albiach et al., 2000) while soil invertase is an important hydrolytic enzyme which can increase the content of soluble nutrients in the soil and can also be used to assess the soil carbon (C) transformation process (Plaza et al., 2004). Soil urease and invertase play an important role in the release of simple $\mathrm{N}$ and $\mathrm{C}$ sources for the multiplication and growth of soil microorganisms (Antonious et al., 2020). Zhang et al. (2016) demonstrated that the application of straw greatly enhanced the activities of soil urease and invertase. Soil cellulase is an enzyme that can accelerate straw decomposition, thereby releasing $\mathrm{C}$ compounds, it contributes to the formation of humus to improve soil fertility (Han and He, 2010). Karami et al. (2012) showed that the application of crop straw increased soil nutrient levels and soil enzyme activity, it also provided a favourable chemical, physical and biological soil environment, which had a positive effect on crop yield and soil productivity. The application of animal manure, as well as straw, contributes to the renewal of soil organic matter which in turn changes the characteristics and amount of soil C and N components (Gao et al., 2018). Jiao et al. (2011) observed that returning straw to the soil promoted the microbial population and microbial biomass $\mathrm{C}$ or $\mathrm{N}$, thereby providing a favourable environment and energy for the accumulation of soil enzymes. Cima et al. (2015) demonstrated that the application of manure contributed to an increase in soil organic C. Zhu et al. (2010) reported that crop yields were significantly increased by straw incorporation based on an eight-year field experiment in China. Several studies have reported the effects of straw or manure incorporation on the properties of soil, but there are few studies to date concerning the biological results of simultaneously returning straw and different animal manures to the soil in dryland farming.
This study aims to determine the combined effect of animal manure and straw on soil enzyme activity levels, microbial quantity, and maize yield in the field, to serve as a reference for agricultural residue management.

\section{MATERIALS AND METHODS}

The experimental site was located in Liaoyuan County, Jilin Province, northeastern China $\left(42^{\circ} 50^{\prime} 55^{\prime \prime} \mathrm{N}\right.$, $\left.125^{\circ} 20^{\prime} 31^{\prime \prime} \mathrm{E}\right)$. The region is very cold during winter and hot during summer, having a temperate continental monsoon climate. The average annual temperature is $5.4^{\circ} \mathrm{C}$, and the mean annual precipitation value is $666.5 \mathrm{~mm}$. The frost-free period is approximately $140 \mathrm{~d}$, and the average yearly sun exposure is $2507 \mathrm{~h}$. The soil is classified as dark-brown soil, the term used is Cryumbreps in the American soil classification system, and Humic Cambisols in WRB with a $\mathrm{pH}$ of 6.3. The total organic $\mathrm{C}$, total $\mathrm{N}$, alkali-hydrolysable $\mathrm{N}$, available $\mathrm{P}$, and available $\mathrm{K}$ in the $0-20 \mathrm{~cm}$ soil layer are $12.3 \mathrm{~g} \mathrm{~kg}^{-1}, 1.3 \mathrm{~g} \mathrm{~kg}^{-1}$, $100.4 \mathrm{mg} \mathrm{kg}^{-1}, 20.3 \mathrm{mg} \mathrm{kg}^{-1}$, and $125.1 \mathrm{mg} \mathrm{kg}^{-1}$ respectively. Artificial irrigation was not applied during the experiment although the location is classified as a dryland area.

The straw was returned to the field by applying the straws in strips. In this method, $20 \mathrm{~cm}$ deep furrows were first created using a plow. Afterwards different animal manures were added to the furrows (according to the respective treatment plot) together with the straw, and finally, the incorporated organic materials were covered by the surrounding soil. Each year (2018 and 2019) the straw and/or animal manure were incorporated in the field before maize was sown in spring. Maize was planted in the ridges during the planting season.

The field was arranged in a randomized block design consisting of four treatments in three replicates. Each plot had a dimension of $10 \mathrm{~m} \times 5 \mathrm{~m}$ and the treatments were maize straw only (S), maize straw plus ox manure (SO), maize straw plus chicken manure (SC), maize straw plus pig manure (SP). The chicken manure, ox manure, and pig manure were collected from chicken farms, ox farms, and pig farms in Liaoyuan County and they were composted for a few months before application. The basic properties of the organic materials used in this study are shown in Table 1. The basic properties of the soil after the application of animal manure combined with straw (AM-S) are shown in Table 2.

In this experiment, the same amount of maize straw (3088 $\mathrm{kg} \mathrm{C} \mathrm{ha}^{-1}$ ) was applied to each plot for each year. The application of animal manure was adjusted so that equal amounts of carbon $\left(7738 \mathrm{~kg} \mathrm{C} \mathrm{ha}^{-1}\right)$ may be applied to each plot in 2018 and 2019. The S treatment received $10826 \mathrm{~kg} \mathrm{Cha}^{-1}$ (from only straw) while the other treatments received $3088 \mathrm{~kg} \mathrm{C}$ ha $^{-1}$ from straw and $7738 \mathrm{~kg} \mathrm{C}^{-1}$ from manure each. The application rate for animal manure was $32500 \mathrm{~kg} \mathrm{ha}^{-1}$ for chicken manure, $25123 \mathrm{~kg} \mathrm{ha}^{-1}$ for ox manure, and $24333 \mathrm{~kg} \mathrm{ha}^{-1}$ for pig manure. 
Table 1. Basic properties of organic materials

\begin{tabular}{|c|c|c|c|c|}
\hline Material & Maize straw & Ox manure & Chicken manure & Pig manure \\
\hline Organic $\mathrm{C}\left(\mathrm{g} \mathrm{kg}^{-1}\right)$ & $423.05 \pm 1.93 \mathrm{a}$ & $308.15 \pm 2.10 \mathrm{c}$ & $238.61 \pm 3.09 \mathrm{~d}$ & $313.54 \pm 2.19 \mathrm{~b}$ \\
\hline Total N $\left(\mathrm{g} \mathrm{kg}^{-1}\right)$ & $6.52 \pm 0.46 \mathrm{~d}$ & $13.25 \pm 0.64 \mathrm{c}$ & $15.77 \pm 0.58 b$ & $17.20 \pm 1.01 \mathrm{a}$ \\
\hline $\mathrm{C} / \mathrm{N}$ & $65.11 \pm 4.47 \mathrm{a}$ & $23.29 \pm 0.97 b$ & $15.14 \pm 0.37 \mathrm{c}$ & $18.27 \pm 0.95 \mathrm{c}$ \\
\hline Lignin $(\%)$ & $6.32 \pm 0.20 \mathrm{~b}$ & $7.23 \pm 0.11 \mathrm{a}$ & $3.21 \pm 0.24 d$ & $5.09 \pm 0.31 \mathrm{c}$ \\
\hline Cellulose $(\%)$ & $32.28 \pm 0.64 \mathrm{a}$ & $23.53 \pm 1.40 \mathrm{~b}$ & $7.04 \pm 0.18 \mathrm{~d}$ & $14.41 \pm 0.24 \mathrm{c}$ \\
\hline Hemicellulose (\%) & $22.37 \pm 1.10 \mathrm{a}$ & $15.38 \pm 0.46 b$ & $4.26 \pm 0.12 \mathrm{~d}$ & $13.24 \pm 0.30 \mathrm{c}$ \\
\hline Polyphenol (\%) & $0.87 \pm 0.02 \mathrm{a}$ & $0.73 \pm 0.10 \mathrm{~b}$ & $0.68 \pm 0.06 \mathrm{~b}$ & $0.69 \pm 0.07 \mathrm{~b}$ \\
\hline Lignin/N & $9.71 \pm 0.38 \mathrm{a}$ & $5.47 \pm 0.35 b$ & $2.04 \pm 0.21 \mathrm{~d}$ & $2.97 \pm 0.35 \mathrm{c}$ \\
\hline Soluble substance $(\%)$ & $32.00 \pm 1.15 \mathrm{~d}$ & $42.24 \pm 0.51 b$ & $40.24 \pm 0.29 \mathrm{c}$ & $47.56 \pm 0.50 \mathrm{a}$ \\
\hline
\end{tabular}

Data with the same letter within the same row do not differ significantly at the $5 \%$ level. Mean \pm standard error. $\mathrm{C}-$ carbon, $\mathrm{N}-$ nitrogen.

Table 2. Basic properties of soil after the application of animal manure combined with straw

\begin{tabular}{lccccccc}
\hline Treatments & $\mathrm{pH}$ & $\mathrm{SOC}\left(\mathrm{g} \mathrm{kg}^{-1}\right)$ & $\mathrm{DOC}\left(\mathrm{mg} \mathrm{kg}^{-1}\right)$ & $\mathrm{EOC}\left(\mathrm{g} \mathrm{kg}^{-1}\right)$ & $\mathrm{MBC}\left(\mathrm{mg} \mathrm{kg}^{-1}\right)$ & $\mathrm{TN}\left(\mathrm{g} \mathrm{kg}^{-1}\right)$ & $\mathrm{AN}\left(\mathrm{mg} \mathrm{kg}^{-1}\right)$ \\
\hline $\mathrm{S}$ & $6.42 \pm 0.43 \mathrm{~d}$ & $14.66 \pm 0.30 \mathrm{c}$ & $138.70 \pm 6.54 \mathrm{c}$ & $1.35 \pm 0.07 \mathrm{~d}$ & $89.54 \pm 3.37 \mathrm{~d}$ & $1.36 \pm 0.07 \mathrm{~b}$ & $118.31 \pm 4.74 \mathrm{c}$ \\
$\mathrm{SO}$ & $6.58 \pm 0.52 \mathrm{c}$ & $16.07 \pm 0.32 \mathrm{~b}$ & $150.57 \pm 8.13 \mathrm{~b}$ & $3.46 \pm 0.09 \mathrm{~b}$ & $124.55 \pm 5.13 \mathrm{a}$ & $1.44 \pm 0.12 \mathrm{~b}$ & $129.60 \pm 8.09 \mathrm{~b}$ \\
$\mathrm{SC}$ & $6.71 \pm 0.91 \mathrm{~b}$ & $17.32 \pm 0.51 \mathrm{a}$ & $154.32 \pm 7.78 \mathrm{ab}$ & $3.19 \pm 0.09 \mathrm{c}$ & $98.13 \pm 2.03 \mathrm{c}$ & $1.66 \pm 0.07 \mathrm{a}$ & $153.94 \pm 3.84 \mathrm{a}$ \\
$\mathrm{SP}$ & $6.84 \pm 0.64 \mathrm{a}$ & $16.61 \pm 0.40 \mathrm{~b}$ & $167.01 \pm 7.64 \mathrm{a}$ & $3.80 \pm 0.09 \mathrm{a}$ & $115.73 \pm 3.96 \mathrm{~b}$ & $1.58 \pm 0.07 \mathrm{a}$ & $139.63 \pm 3.10 \mathrm{~b}$ \\
\hline
\end{tabular}

SOC - soil organic carbon, EOC - easily oxidizable carbon, DOC - dissolved organic carbon, MBC - microbial biomass carbon, TN total nitrogen, $\mathrm{AN}$ - available nitrogen, $\mathrm{S}$ - maize straw only, $\mathrm{SO}$ - maize straw plus ox manure, $\mathrm{SC}$ - maize straw plus chicken manure, $\mathrm{SP}$ - maize straw plus pig manure. Other explanation as in Table 2.

Soil samples were collected in October 2018 and 2019. Five soil cores were randomly collected from each plot following the "S" method at a depth of $0-20 \mathrm{~cm}$. All samples were packed into aseptic PET resin bags, placed in iceboxes and taken to the laboratory for further processing. The soil samples were immediately stored in a refrigerator at $4^{\circ} \mathrm{C}$. One part was used for soil enzyme analysis and the other part was used for soil microbial quantity determination.

The moisture content was determined using the ovendrying method, that is, samples were dried in an oven at a temperature of $105^{\circ} \mathrm{C}$ until a constant mass was reached. The activities of soil urease and catalase were determined following the methods described by Zhang et al. (2011). The activity of soil invertase was determined according to methods described by Parthasarathi and Ranganathan (2000). The activity of soil cellulase was measured using 3,5-dinitrosalicylic acid colorimetry (Breuil and Saddler, 1985). The blank (reagents) and reference samples (only soil without reagents) were used to measure soil enzyme activity (as mentioned in the sample test). The activity of soil cellulase was measured by weighing $5 \mathrm{~g}$ of a soil sample into a shaking bottle and adding $10 \mathrm{~mL}$ of carboxymethyl cellulose solution, $5 \mathrm{~mL}$ acetate buffer ( $\mathrm{pH} 4.8$ ) and $0.1 \mathrm{~mL}$ toluene. After the sample was fully mixed, it was placed in an incubator at $37^{\circ} \mathrm{C}$ for $72 \mathrm{~h}$. The glucose released by cellulase was measured by 3,5 -dinitrosalicylic acid colorimetry in a spectrophotometer at $540 \mathrm{~nm}$. In order to analyse the urease activity in the soil, urea solution was used as a substrate. Fresh soil $(5 \mathrm{~g})$ was incubated at $37^{\circ} \mathrm{C}$ with $5 \mathrm{~mL}$ of substrate and $5 \mathrm{~mL}$ of citrate buffer ( $\mathrm{pH}$ of 6.7) for $24 \mathrm{~h}$. The reaction mixture was diluted to $50 \mathrm{~mL}$ with distilled water. The urea was hydrolysed to ammonium nitrogen through the catalysis of urease. The level of ammonium was measured in a spectrophotometer at $578 \mathrm{~nm}$. The activity of soil urease was determined from the filtered mixture using the phenol-sodium hypochlorite colorimetric method (Zhang et al., 2011). The activity of soil catalase was measured by weighing $2 \mathrm{~g}$ of fresh soil into a shaking bottle and adding $40 \mathrm{~mL}$ of distilled water and $5 \mathrm{~mL}$ of $0.3 \% \mathrm{H}_{2} \mathrm{O}_{2}$. After the sample was fully mixed, it was placed in an oscillator and shaken for 20 minutes. After filtration, $5 \mathrm{~mL}$ of $3 \mathrm{~mol} \mathrm{~L}^{-1}$ sulfuric acid was added to the filtrate, and the filtrate was titrated with $0.1 \mathrm{~mol} \mathrm{~L}^{-1} \mathrm{KMnO}_{4}$ (Zhang et al., 2011). In order to analyse the activity of the soil invertase, a glucose solution was used as the substrate wherein a $5 \mathrm{~g}$ soil sample was incubated at $37^{\circ} \mathrm{C}$ with $15 \mathrm{~mL}$ of the substrate, $0.1 \mathrm{~mL}$ toluene, and $5 \mathrm{~mL}$ phosphate buffer ( $\mathrm{pH} 5.5$ ). The glucose released by invertase was determined using 3,5-dinitrosalicylic acid colorimetry (Parthasarathi and Ranganathan, 2000). The glucose was analysed colorimetrically at $508 \mathrm{~nm}$.

The activity of the soil enzyme was expressed in terms of the dry soil weight. The activities of soil urease, catalase, invertase, and cellulase were expressed in terms of $\mathrm{mg} \mathrm{NH}{ }_{4}^{+}-\mathrm{N} \mathrm{g}^{-1}$ soil $24 \mathrm{~h}^{-1}, 0.1 \mathrm{~mol} \mathrm{~L}^{-1} \mathrm{KMnO}_{4} \mathrm{~g}^{-1}$ soil $20 \mathrm{~min}^{-1}$, mg glucose $\mathrm{g}^{-1}$ soil $24 \mathrm{~h}^{-1}$, mg glucose $\mathrm{kg}^{-1}$ soil $72 \mathrm{~h}^{-1}$, respectively. The activities of soil urease, invertase, and cellulase were calculated using the following Eq. (1),

$$
E=(a-b-c) \frac{n}{m},
$$

where: $E$ is the activity of the soil enzyme; $a, b, c$ are the contents of the measured substance (mg) corresponding to the optical density values of the test sample, reagent, and reference sample on the standard curve respectively; $n$ is the split multiple; $m$ is the mass of the soil sample (g).

The activity of soil catalase was calculated using the following Eq. (2), 
The activity of soil catalase $=(A-B) \frac{T}{M}$,

where: $A$ is the amount of $\mathrm{KMnO}_{4}(\mathrm{~mL})$ consumed by the titrating reagent, and $B$ is the amount of $\mathrm{KMnO}_{4}(\mathrm{~mL})$ consumed by the titrating soil sample, $T$ is the correction value of the $\mathrm{KMnO}_{4}$ titration, $M$ is the mass of the soil sample (g).

The microbial quantity was determined using the plate count method. The bacteria were cultivated in a beefprotein medium at $37^{\circ} \mathrm{C}$ for $7 \mathrm{~d}$, the actinomycetes were cultivated at $28^{\circ} \mathrm{C}$ for 7 days using GAUZE's medium and the fungi were cultivated in Martin medium at $28^{\circ} \mathrm{C}$ for 7 days (Zhou, 1993). The number of microbial colonies was counted and recorded in order to calculate the number of microorganisms per gram of dry soil ( $\mathrm{cfu} \mathrm{g}^{-1}$ dry soil).

The three central rows of maize with a length of $5 \mathrm{~m}$ for each plot were manually harvested, then the grain yield was determined at $12 \%$ grain moisture content.

Statistical analyses were carried out using the SPSS 17.0 statistical software (SPSS). The means and standard errors for three replicates were calculated. A one-way analysis of variance (ANOVA) was used to evaluate the differences in the selected parameters (e.g. the properties of organic materials and soil, soil enzymes, microbial quantity and yield). A two-way ANOVA was carried out to assess the effect of the experimental year and the various treatments on microbial quantity, soil enzyme activities and yield. Pearson's correlation analysis was used to investigate the relationship between microbial quantity, soil enzyme activities, and yield. Multiple comparisons were carried out using Duncan's new multiple ranges test. Significant differences between treatments were set at confidence levels of $p<0.05$ and $p<0.01$.

\section{RESULTS}

Compared with the $S$ treatment, higher yields $(\mathrm{p}<0.01)$ were achieved in the treatments with AM-S (Fig. 1). The yields for 2018 and 2019 followed the order $\mathrm{SP}>\mathrm{SO}>\mathrm{SC}>\mathrm{S}$, and were 5.9-12.0\% higher in 2019 than in 2018. Compared with the S treatment, the AM-S-treated plots significantly increased the yield by $17.8-31.0 \%$ in 2018 and $24.0-32.4 \%$ in $2019(\mathrm{p}<0.05)$. In 2018, compared with SO and SC, the yield from SP was 5.4 and $11.2 \%$ higher respectively, whereas in 2019, the yield from SP was 0.7 and $6.7 \%$ higher than from SO and SC, respectively (Fig. 1).

The enzyme activity for the different treatments is shown in Fig. 2. Compared with S, higher urease activities were observed for the AM-S treatments $(\mathrm{p}<0.01)$. The urease activity levels followed the order $\mathrm{SP}>\mathrm{SC}>\mathrm{SO}>\mathrm{S}$ in both 2018 and 2019 and were $17.1-41.8 \%$ higher in 2019 than in 2018. Urease activity with the SP, SO, and SC treatments were 56.1, 51.6, and $37.0 \%$ higher than those with the $\mathrm{S}$ treatment in 2019, respectively $(\mathrm{p}<0.01)$.

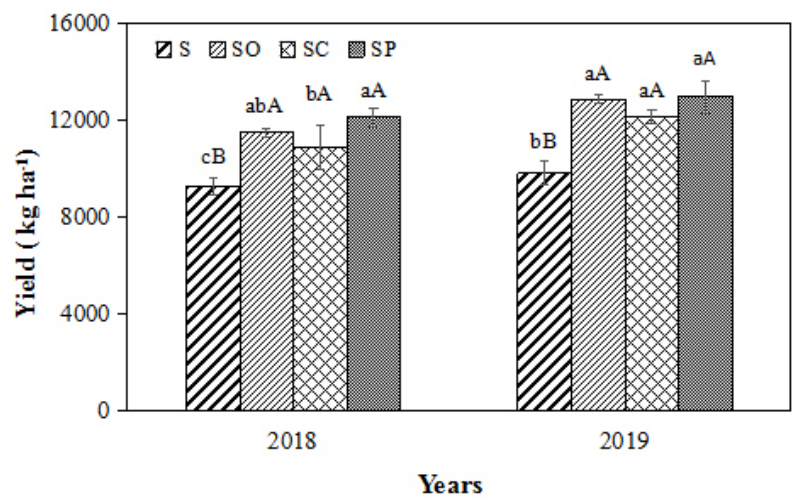

Fig. 1. The maize yields after the application of maize straw and manure in 2018 and 2019. Note: Bars represent the standard errors of three replications. Different lowercase and capital letters above the bars in the same year indicated significance among the treatments at $\mathrm{p}<0.05$ and $\mathrm{p}<0.01$, respectively. $\mathrm{S}-$ maize straw only, $\mathrm{SO}$ - maize straw plus ox manure, $\mathrm{SC}$ - maize straw plus chicken manure, $\mathrm{SP}-$ maize straw plus pig manure.

Compared to 2018, the catalase content was greater in 2019. The soil catalase contents were ranked as follows: $\mathrm{SO}>\mathrm{SP}>\mathrm{SC}>\mathrm{S}$ in both 2018 and 2019. Compared to the $\mathrm{S}$ treatment, the catalase content in the SO treated soils significantly increased by 37.7 and $51.6 \%$ in 2018 and 2019 , respectively $(\mathrm{p}<0.01)$.

The invertase activity of soil significantly increased in the AM-S treatments compared to the $\mathrm{S}(\mathrm{p}<0.01)$, and the activity of invertase followed the order $\mathrm{SP}>\mathrm{SC}>\mathrm{SO}>\mathrm{S}$ in both years and were 18.9-30.6\% higher in 2019 than in 2018. In 2018 and 2019, the invertase activity in SP was 38.9 and $32.8 \%$ higher than that of $\mathrm{S}$, respectively $(\mathrm{p}<0.01)$.

The soil cellulase activity followed the order $\mathrm{SO}>\mathrm{SC}>\mathrm{SP}>\mathrm{S}$ in 2018 and 2019 and was $6.9-13.0 \%$ higher in 2019 than in 2018 . The cellulase activity of SO, SC, and SP were $45.0,26.9$, and $8.6 \%$ higher respectively compared with $\mathrm{S}$ in 2019.

The effects of AM-S on the soil microbial quantity are shown in Table 3. Compared to S, the AM-S treated soils significantly increased their microbial quantity in both years. In 2018 and 2019, the highest quantity of soil bacteria was recorded for the SO treatment. Moreover, the fungal quantity in the SP, SC and SO treated soils were 52.0, 18.4, and 40.1\% higher than for the $\mathrm{S}$ treatment in 2019 , respectively. Compared with $\mathrm{S}$, the quantity of actinomycetes after the applications of SO and SC increased by 57.8 and $87.9 \%$ respectively, while SP had little impact on their quantity in 2019.

The two-way ANOVA results showed that the experimental year and the treatments were the main factors influencing the microbial quantity, soil enzyme activities, and yield parameters (Table 4). The AM-S treatments had a significant effect on microbial quantity, soil enzyme activity, and yield $(p<0.01)$. Similarly, the effect of the experimental years was significant for yield, soil enzyme activities, and fungal quantity $(\mathrm{p}<0.01)$. The interactions 

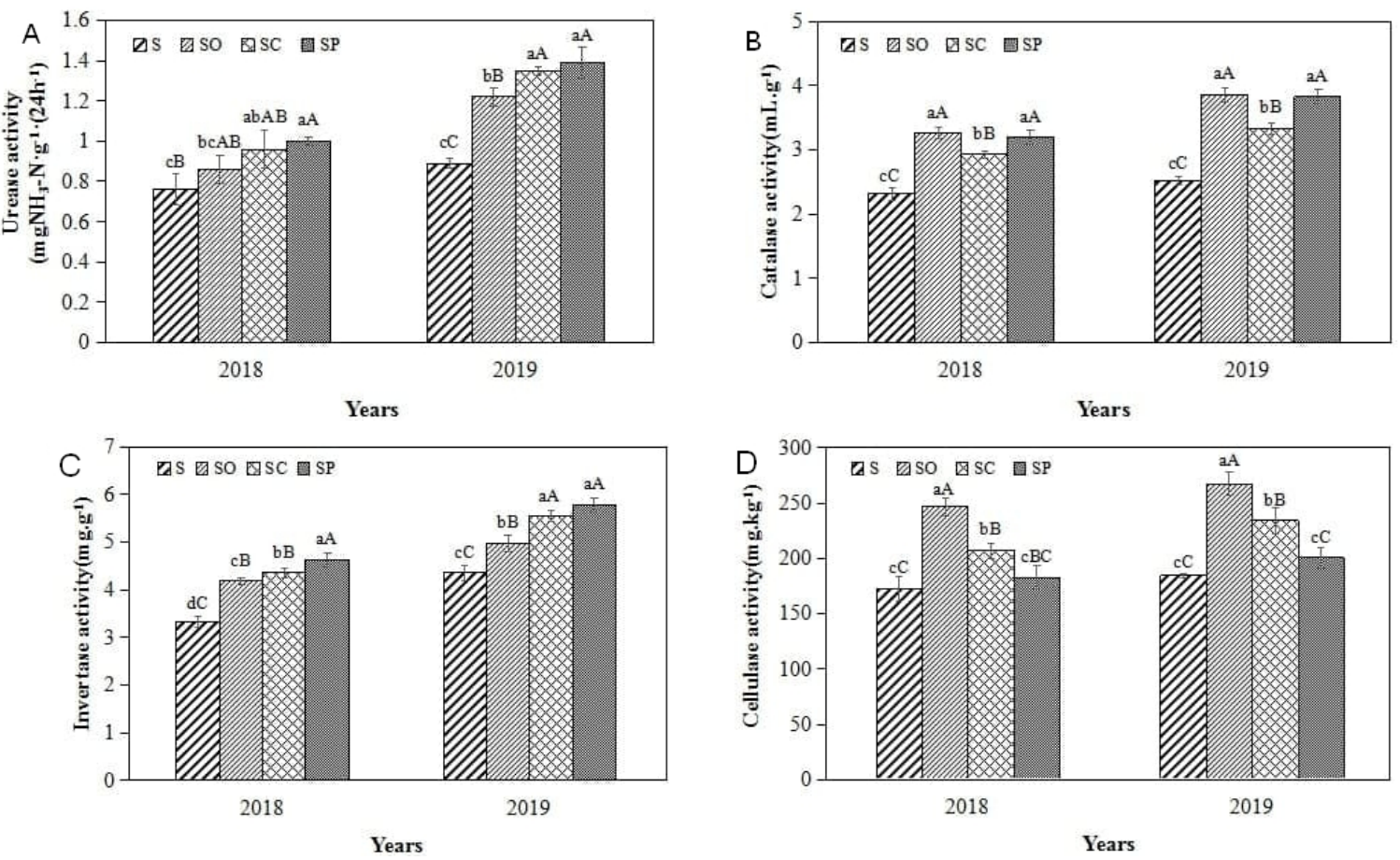

Fig. 2. Soil enzymatic activities after the application of maize straw and manure in 2018 and 2019. Note: A, B, C, and D represent soil urease activity, catalase activity, invertase activity, and cellulase activity respectively. For significant difference among treatments, seen in Fig. 1. S - maize straw only, $\mathrm{SO}$ - maize straw plus ox manure, $\mathrm{SC}$ - maize straw plus chicken manure, $\mathrm{SP}$ - maize straw plus pig manure.

Table 3. Effect of animal manure combined with straw on the number of microorganisms in the soil

\begin{tabular}{|c|c|c|c|c|c|c|}
\hline \multirow[t]{2}{*}{ Treatments } & \multicolumn{2}{|c|}{$\begin{array}{l}\text { Bacterial quantity } \\
\left(\times 10^{6} \text { cfu g }^{-1} \text { soil }\right)\end{array}$} & \multicolumn{2}{|c|}{$\begin{array}{l}\text { Fungal quantity } \\
\left(\times 10^{3} \text { cfu g }^{-1} \text { soil }\right)\end{array}$} & \multicolumn{2}{|c|}{$\begin{array}{l}\text { Actinomyces quantity } \\
\left(\times 10^{4} \text { cfu g }^{-1} \text { soil }\right)\end{array}$} \\
\hline & 2018 & 2019 & 2018 & 2019 & 2018 & 2019 \\
\hline $\mathrm{S}$ & $2.4 \pm 0.1 d$ & $2.5 \pm 0.2 \mathrm{c}$ & $3.6 \pm 0.2 \mathrm{c}$ & $4.5 \pm 0.4 d$ & $4.3 \pm 0.3 d$ & $4.2 \pm 0.2 \mathrm{c}$ \\
\hline SO & $8.4 \pm 0.1 \mathrm{a}$ & $8.0 \pm 0.5 \mathrm{a}$ & $5.6 \pm 0.3 b$ & $6.3 \pm 0.1 b$ & $6.3 \pm 0.1 b$ & $6.6 \pm 0.2 b$ \\
\hline $\mathrm{SC}$ & $4.8 \pm 0.5 \mathrm{c}$ & $5.0 \pm 0.4 \mathrm{~b}$ & $5.2 \pm 0.2 b$ & $5.3 \pm 0.2 \mathrm{c}$ & $7.3 \pm 0.1 \mathrm{a}$ & $7.9 \pm 0.2 \mathrm{a}$ \\
\hline SP & $7.4 \pm 0.2 b$ & $7.8 \pm 0.1 \mathrm{a}$ & $6.5 \pm 0.2 \mathrm{a}$ & $6.8 \pm 0.1 \mathrm{a}$ & $5.3 \pm 0.1 \mathrm{c}$ & $5.2 \pm 0.1 \mathrm{c}$ \\
\hline
\end{tabular}

Other explanation as in Table 1 and 2.

Table 4. Effects of treatments, year of experiment, and their interactions (two-way ANOVA) on bacterial quantity, fungal quantity, actinomyces quantity, soil urease activity, catalase activity, invertase activity, cellulase activity and yield

\begin{tabular}{|c|c|c|c|c|c|c|c|c|c|c|c|c|c|c|c|c|}
\hline \multirow[t]{2}{*}{ Main effects } & \multicolumn{2}{|c|}{ Yield } & \multicolumn{2}{|c|}{$\begin{array}{l}\text { Urease } \\
\text { activity }\end{array}$} & \multicolumn{2}{|c|}{$\begin{array}{l}\text { Catalase } \\
\text { activity }\end{array}$} & \multicolumn{2}{|c|}{$\begin{array}{l}\text { Invertase } \\
\text { activity }\end{array}$} & \multicolumn{2}{|c|}{$\begin{array}{l}\text { Cellulase } \\
\text { activity }\end{array}$} & \multicolumn{2}{|c|}{$\begin{array}{l}\text { Bacterial } \\
\text { quantity }\end{array}$} & \multicolumn{2}{|c|}{$\begin{array}{c}\text { Fungal } \\
\text { quantity }\end{array}$} & \multicolumn{2}{|c|}{$\begin{array}{c}\text { Actinomyces } \\
\text { quantity }\end{array}$} \\
\hline & F valu & & F value & Sig. & $\mathrm{F}$ value & Sig. & F value & Sig. & F value & Sig. & F value & Sig. & $\mathrm{F}$ value & Sig. & F value & Sig. \\
\hline Trea & 44.59 & $* *$ & 45.90 & $* *$ & 283.90 & $* *$ & 153.72 & $* *$ & 85.89 & $* *$ & 515.48 & $* *$ & 154.49 & $* *$ & 237.33 & $* *$ \\
\hline Years ( & 24.79 & $* *$ & 168.71 & $* *$ & 219.85 & $* *$ & 473.14 & $* *$ & 26.63 & $* *$ & 1.02 & $\mathrm{~ns}$ & 28.75 & $* *$ & 4.54 & $*$ \\
\hline$T \times Y$ & 0.89 & ns & 6.48 & $* *$ & 10.05 & $* *$ & 3.73 & * & 0.71 & ns & 1.93 & ns & 3.88 & $*$ & 2.89 & $\mathrm{~ns}$ \\
\hline
\end{tabular}

* significant at $\mathrm{p}<0.05, * *$ significant at $\mathrm{p}<0.01, \mathrm{~ns}-$ not significant, $\mathrm{n}=48$.

Table 5. Correlations among microbial quantity, soil urease activity, catalase activity, invertase activity, cellulase activity and yield

\begin{tabular}{|c|c|c|c|c|c|c|c|c|}
\hline & Yield & Urease & Catalase & Invertase & Cellulase & $\begin{array}{l}\text { Bacterial } \\
\text { quantity }\end{array}$ & $\begin{array}{c}\text { Fungal } \\
\text { quantity }\end{array}$ & $\begin{array}{c}\text { Actinomycetes } \\
\text { quantity }\end{array}$ \\
\hline Yield & 1.000 & & & & & & & \\
\hline Urease & $0.813 * *$ & 1.000 & & & & & & \\
\hline Catalase & $0.949 * *$ & $0.803 * *$ & 1.000 & & & & & \\
\hline Invertase & $0.751 * *$ & $0.928 * *$ & $0.699 *$ & 1.000 & & & & \\
\hline Cellulase & $0.594 *$ & 0.369 & $0.597 *$ & 0.207 & 1.000 & & & \\
\hline Bacterial quantity & $0.900 * *$ & $0.708 * *$ & $0.973 *$ & $0.617 *$ & $0.586 *$ & 1.000 & & \\
\hline Fungal quantity & $0.858 * *$ & $0.714 * *$ & $0.921 * *$ & $0.701 *$ & 0.385 & $0.953 * *$ & 1.000 & \\
\hline Actinomycic quantity & 0.517 & $0.618^{*}$ & 0.437 & 0.493 & $0.745 * *$ & 0.316 & 0.162 & 1.000 \\
\hline
\end{tabular}

Date were collected in 2019 . ${ }^{*}$ significant at $\mathrm{p}<0.05, * *$ significant at $\mathrm{p}<0.01, \mathrm{n}=24$. 
between the treatments and experimental years were significant at $\mathrm{p}<0.01$ for soil urease activity and catalase activity, and at $p<0.05$, the interactions had a significant effect on invertase activity and fungal quantity.

The correlation results showed that yield was positively correlated with urease activity $(\mathrm{r}=0.813, \mathrm{p}<0.01)$, catalase activity $(\mathrm{r}=0.949, \mathrm{p}<0.01)$, invertase activity $(\mathrm{r}=0.751$, $\mathrm{p}<0.01)$, cellulase activity $(\mathrm{r}=0.594, \mathrm{p}<0.05)$, bacterial quantity $(\mathrm{r}=0.900, \mathrm{p}<0.01)$, and fungal quantity $(\mathrm{r}=0.858$, $\mathrm{p}<0.01$ ) (Table 5). Moreover, the urease activity exhibited a positive correlation with the catalase activity, invertase activity, bacterial quantity, and fungal quantity $(\mathrm{p}<0.01)$. Similarly, catalase activity also showed a positive correlation with bacterial quantity, invertase activity, cellulase activity $(\mathrm{p}<0.05)$, and fungal quantity $(\mathrm{p}<0.01)$. In addition, a positive relationship was found between the invertase activity, bacterial quantity, and fungal quantity $(\mathrm{p}<0.05)$.

\section{DISCUSSION}

Some studies have shown that the incorporation of organic wastes and maize straw applications into the soil increases soil fertility and crop yields (Maltas et al., 2018, Mandal et al., 2013). In our study, the AM-S treatments increased maize yield, this was possibly due to the use of animal manure as an additional $\mathrm{C}$ source. In addition, other properties of the soil such as $\mathrm{pH}$ and available $\mathrm{C}$ and $\mathrm{N}$ content in the soil (Table 2), structure, and microbial activity were enhanced to create favourable soil conditions supporting maize yield ( $\mathrm{Li}$ et al., 2020). The higher yield in SP treatment may be due to the fact that pig manure contains more organic carbon and soluble components (Table 1), which are more accessible to microorganisms to improve soil conditions for crop growth (Wu et al., 2017).

Various soil enzymes are important indicators for soil biochemistry and fertility and are involved in the conversion processes and biological cycling of soil nutrients (Maxwell et al., 2020). In our study, when compared with S, the AM-S treatments greatly increased the activities of soil enzymes under straw and manure. The activity of urease in the soil can be used to represent the $\mathrm{N}$ supply capacity of the soil, and the improvement of urease is conducive to the conversion of organic $\mathrm{N}$ in the soil to available $\mathrm{N}$ which may be absorbed and utilized by plants (Cao et al., 2016). In our study, urease activity under $\mathrm{S}$ treatment was relatively low, while the AM-S treatments had a higher urease activity. Previous studies showed that the application of organic manure increased the content of urease in the soil, which was similar to the results achieved by our study (Ghollarata and Raiesi, 2007). The enhancement of soil urease activity in SC and SP was mainly due to chicken and pig manure which is rich in nitrogen and provides an adequate substrate for urease-producing microorganisms (Wei et al., 2010). Moreover, chicken and pig manure have a low $\mathrm{C} / \mathrm{N}$ ratio (Table 1), hence the incorporation of straw regulated the $\mathrm{C} / \mathrm{N}$ ratio thereby creating favourable conditions for the improvement of microbial activities and enzyme activity (Zhang et al., 2020).

Catalase is an important redox enzyme in the soil which can decompose hydrogen peroxide in the soil and prevent crops from being poisoned (Huang et al., 2014). In 2019, catalase activity was higher than it was in 2018 , which may be due to the accumulation of nutrients after the return of animal manure and straw to the field in each year (Samuel et al., 2008). The ox manure accelerated soil $\mathrm{C}$ and $\mathrm{N}$ cycling and provided a significant amount of nutrients and C for catalase-producing microorganisms thereby improving the soil quality and catalase activities (Bowles et al., 2014). Soil catalase activity is associated with soil organic matter content, respiration, and the activity of the soil microbial community (Brzezińska et al., 2005). The activity of catalase in the SC treatment was lower, which may be due to the fact that chicken manure contains relatively less organic matter and fewer catalase-producing microorganisms compared to pig and ox manure. Zhang et al. (2016, 2020) similarly attributed the increases in soil enzymatic activities to increases in soil carbon content due to the addition of organic fertilizer (Table 2).

Soil invertase is directly involved in the metabolism of organic matter and can be used to represent the soil fertility index and soil biological activity (Plaza et al., 2004). In this study, compared with other treatments, the highest activity of soil invertase was recorded under SP. This may be because pig manure contains more organic $\mathrm{C}$, which increases the amount of soil organic matter and substrate for enzymes after its application to the field, thus enhancing enzyme activity (Bocar et al., 2009). Similarly, Wei et al. (2015) and Sharma et al. (2020) respectively reported increases in soil invertase and enzymatic activity due to an increase in soil organic matter and organic $\mathrm{C}$ content.

Cellulase is particularly important in the $\mathrm{C}$ cycle (Gander et al., 1994). In our study, it was found that compared with other treatments, the activity of soil cellulase under the SO treatment was higher. This may be due to the release of cellulose after the application of SO thereby promoting the enhancement of cellulase activity. This improved the cellulose decomposition rate which in turn lead to the production of more glucose and other metabolites to provide more and better nutrients for maize growth (Shi et al., 2019). The organic waste treatments were applied annually, the materials that failed to decompose from 2018 would later decompose in 2019 to improve the soil environment, enhance microbial activity, and thus increase enzyme activity and yield. This phenomenon also applies to the control group though only straw was applied.

The activity of soil enzymes is closely related to the activities of microbial communities and has become an important indicator of microbial ecological status (Yan et al., 2018). In the present study, the AM-S-treated soils significantly increased the microbial quantity. This 
corresponds to the small size of the microbial community which is responsible for microbiological changes in the environment. The utilization of chemical nutrients and rich organic matter produced by the farm manure may improve soil conditions, further increase the number of soil microorganisms and the activity of enzymes, and thus accelerate the straw nutrient release rate (Singh et al., 2016).

The findings of this study confirmed the relationship between the soil microbial quantity and enzymatic activities and crop yield as it had been ascertained by previous studies (Karami et al., 2012; Tripathy and Singh, 2004). In our study, soil enzymes (invertase, urease, and catalase) had a close relationship with soil bacterial quantity and fungal quantity. This indicated that the changes to soil microorganisms were closely related to soil enzyme activity (Evgenia and Yakov, 2013). In this paper, the yield was positively correlated with soil microbial quantity and enzyme activity and also the application of AM-S increased microbial quantity and soil enzyme activity, thus increasing the yield. This shows that improving soil microbial and enzymatic activities through the application of organic wastes enhances the soil conditions for crops thereby improving the growth and yield of crops. The results of this study may help to alleviate the shortcomings of the traditional modes of straw application and also provide a reference for straw and animal manure management. Further research should characterize soil microbial communities after the application of animal manure and straw using next-generation sequencing and help to identify their relationships with labile organic $\mathrm{C}$ fractions in the soil.

\section{CONCLUSIONS}

1. In our two-year study, the combination of animal manure with straw improved soil enzyme activity, microbial quantity, and the yield of maize, however, the effects varied in each treatment.

2. The catalase activities were higher for the maize straw plus ox manure and maize straw plus pig manure treatments, while the highest cellulase activities were recorded in the maize straw plus ox manure and maize straw plus chicken manure treatments. The invertase and urease activities in maize straw plus pig manure were higher compared to other treatments.

3. A higher quantity of actinomycetes was achieved for the treatments amended with maize straw plus chicken manure and maize straw plus ox manure as compared to other treatments. The highest number of soil bacteria was recorded in the maize straw plus ox manure treatment.

4. Maize straw plus pig manure had the highest maize yield and significantly improved the fungal quantity, urease activities, and invertase activities. We recommend the application of pig manure combined with straw as the most effective agronomic practice for improving the activity of soil enzymes, microbial quantity, and crop yields.
5. Only the microbial quantity of soil was tested in the present study, therefore, future research will be required to identify the microbial community using next-generation sequencing. This will provide more information concerning changes to the microbial community occurring as a result of the application of various treatments.

Conflict of interest: The authors declare no conflict of interest.

\section{REFERENCES}

Albiach R., Canet R., Pomares F., and Ingelmo F., 2000. Microbial biomass content and enzymatic activities after the application of organic amendments to a horticultural soil. Bioresour. Technol., 75, 43-48, https://doi.org/10.1016/ S0960-8524(00)00030-4

Antonious G.F., Turley E.T., and Dawood M.H., 2020. Monitoring soil enzymes activity before and after animal manure application. Agric., 10(5), 166, https://doi. org/10.3390/agriculture10050166

Benavente I., Gascó G., Plaza C., Paz-Ferreiro J., and Méndez A., 2018. Choice of pyrolysis parameters for urban wastes affects soil enzymes and plant germination in a Mediterranean soil. Sci. Total Environ., 634(SEP.1), 1308-1314, https://doi.org/10.1016/j.scitotenv.2018.04.120

Blumfield T.J. and Xu Z.H., 2003. Impact of harvest residues on soil mineral nitrogen dynamics following clear fall harvesting of a hoop pine plantation in subtropical Australia. For. Ecol. Manag., 179, 55-67, https://doi.org/10.1016/S03781127(02)00485-1

Bocar A., Huang Q.Y., Chen W.L., Wen S.L., Zhang J.Y., Mohamed I., Cai P., and Liang W., 2009. Microcalorimetric assessment of microbial activity in long-term fertilization experimental soils of Southern China. FEMS Microbiol. Ecol., 2, 30-39.

Bowles T.M., Acosta-Martínez V., Calderón F., and Jackson L.E., 2014. Soil enzyme activities, microbial communities, and carbon and nitrogen availability in organic agroecosystems across an intensively-managed agricultural landscape. Soil Biol. Biochem., 68, 252-262, https://doi.org/10.1016/j. soilbio.2013.10.004

Breuil C. and Saddler J., 1985. Comparison of the 3,5-dinitrosalicylic acid and Nelson-Somogyi methods of assaying for reducing sugars and determining cellulase activity. Enzyme Microb. Technol., 7, 327-332, https://doi.org/10.1016/01410229(85)90111-5

Brzezińska M., Włodarczyk T., Stępniewski W., and Przywara G., 2005. Soil aeration status and catalase activity. Acta Agroph., 5, 555-565.

Cao J., Wang C., Ji D., 2016. Improvement of the soil nitrogen content and maize growth by earthworms and arbuscular mycorrhizal fungi in soils polluted by oxytetracycline. Sci. Total Environ., 571 (Nov. 15), 926-934, https://doi.org/10.1016/j. scitotenv.2016.07.077

Cima D., Luik A., and Reintam E., 2015. Organic farming and cover crops as an alternative to mineral fertilizers to improve soil physical properties. Int. Agrophys., 29, 405-412, https:/doi.org/10.1515/intag-2015-0056 
Cusack D.F., Silver W.L., Torn M.S., Burton S.D., and Firestone M.K., 2011. Changes in microbial community characteristics and soil organic matter with nitrogen additions in two tropical forests. Ecology, 92, 621-632, https:// doi.org/10.1890/10-0459.1

Dominik A., Franz Z., and Simone J., 2018. Activated biochar alters activities of carbon and nitrogen acquiring soil enzymes. Pedobiologia, 69, 1-10, https://doi.org/10.1016/j. pedobi.2018.06.001

Evgenia B. and Yakov K., 2013. Active microorganisms in soil: Critical review of estimation criteria and approaches. Soil Biol. Biochem., 67, 192-211, https://doi.org/10.1016/j.soilbio.2013.08.024

Gajda A.M., Przewłoka B., and Gawryjołek K., 2013. Changes in soil quality associated with tillage system applied. Int. Agrophys., 2013, 27, 133-141, https://doi.org/10.2478/ v10247-012-0078-7

Gander L.K., Hendricks C.W., and Doyle J.D., 1994. Interferences, limitations and an improvement in the extraction and assessment of cellulase activity in soil. Soil Biol. Biochem., 26(1), 65-73, https://doi.org/10.1016/0038-0717(94)90196-1

Gao S., Gao J., Cao W., Zou C., Huang J., Bai J., and Dou F., 2018. Effects of long-term green manure application on the content and structure of dissolved organic matter in red paddy soil. J. Integr. Agr., 17(8), 1852-1860, https://doi.org/10.1016/S20953119(17)61901-4

Ghollarata M. and Raiesi F., 2007. The adverse effects of soil salinization on the growth of Trifolium alexandrinum L. and associated microbial and biochemical properties in a soil from Iran. Soil Biol. Biochem., 39(7), 1699-1702, https://doi.org/10.1016/j.soilbio.2007.01.024

Han W. and He M., 2010. The application of exogenous cellulase to improve soil fertility and plant growth due to acceleration of straw decomposition. Bioresour. Technol., 101, 3724-3731, https://doi.org/10.1016/j.biortech.2009.12.104

Hou X.Q., Li R., Jia Z.K., Han Q.F., Yang B.P., and Nie J.F., 2012. Effects of rotational tillage practices on soil structure, organic carbon concentration, and crop yields in semi-arid areas of northwest China. Soil Use Manag., 28, 551-558.

Huang X., Xue D., and Xue L., 2014. Changes in microbial biomass, activity, functional diversity, and enzyme activity in tree peony (Paeonia suffruticosa) garden soils. Hortence, 49(11), 1408-1413, https://doi.org/10.21273/HORTSCI.49.11.1408

Hu N., Wang B., Gu Z., Tao B., Zhang Z., Hu S., Zhu L., and Meng Y., 2016. Effects of different straw returning modes on greenhouse gas emissions and crop yields in a ricewheat rotation system. Agric. Ecosyst. Environ., 223, 115-122, https://doi.org/10.1111/j.1475-2743.2012.00429.x

Jian S., Li J., Chen J., Wang G., Mayes M.A., Dzantor K.E., Hui D., and Luo Y., 2016. Soil extracellular enzyme activities, soil carbon and nitrogen storage under nitrogen fertilization: A meta-analysis. Soil Biol. Biochem., 101, 3243, https://doi.org/10.1016/j.soilbio.2016.07.003

Jiao X.G., Gao C.S., Lü G.H., and Sui Y.Y., 2011. Effect of long-term fertilization on soil enzyme activities under different hydrothermal conditions in Northeast China. Agr. Sci. China, 10, 412-422, https://doi.org/10.1016/S16712927(11)60020-5

Ji L.Q., 2015. An assessment of agricultural residue resources for liquid biofuel production in China. Renew. Sust. Energ. Rev., 44, 561-575, https://doi.org/10.1016/j.rser.2015.01.011
Karami A., Homaee M., Afzalinia S., Ruhipour H., and Basirat S., 2012. Organic resource management: impacts on soil aggregate stability and other soil physicochemical properties. Agr. Ecosyst. Environ., 148, 22-28, https://doi. org/10.1016/j.agee.2011.10.021

Kumar S., Paritosh K., Pareek N., Chawade A., and Vivekanand V., 2018. De-construction of major Indian cereal crop residues through chemical pretreatment for improved biogas production: An overview. Renew. Sust. Energ. Rev., 90, 160-170, https://doi.org/10.1016/j.rser.2018.03.049

Lafond G.P., Stumborg M., Lemke R., May W.E., Holzapfel C.B., and Campbell C.A., 2009. Quantifying straw removal through baling and measuring the long-term impact on soil quality and wheat production. Agronomy J., 101, 529537, https://doi.org/10.2134/agronj2008.0118x

Li T., Zhang Y., Bei S., Li X., Reinsch S., Zhang H., and Zhang J., 2020. Contrasting impacts of manure and inorganic fertilizer applications for nine years on soil organic carbon and its labile fractions in bulk soil and soil aggregates. Catena, 194, 104739, https://doi.org/10.1016/j. catena.2020.104739

Maltas A., Kebli H., Oberholzer H.R., Weisskopf P., and Sinaj S., 2018. The effects of organic and mineral fertilizers on carbon sequestration, soil properties, and crop yields from a long-term field experiment under a Swiss conventional farming system. Land Degrad. Dev., 29, 926-938, https://doi.org/10.1002/ldr.2913

Mandal N., Dwivedi B.S., Meena M.C., Singh D., Datta S.P., Tomar R.K., and Sharma B.M., 2013. Effect of induced defoliation in pigeonpea, farmyard manure and sulphitation pressmud on soil organic carbon fractions, mineral nitrogen and crop yields in a pigeonpea-wheat cropping system. Field Crops Res., 154(6), 178-187, https://doi.org/10.1016/j. fcr.2013.08.007

Maxwell T.L., Augusto L., Bon L., Adèle Courbineau., and Fanin N., 2020. Effect of a tree mixture and water availability on soil nutrients and extracellular enzyme activities along the soil profile in an experimental forest. Soil Biol. Biochem., 107864, https://doi.org/10.1016/j.soilbio.2020.107864

Mierzwa-Hersztek M., Gondek K., Klimkowicz-Pawlas A., Chmiel M.J., Dziedzic K., and Taras H., 2019. Assessment of soil quality after biochar application based on enzymatic activity and microbial composition. Int. Agrophys., 33(3), 331-336, https://doi.org/10.31545/intagr/110807

Parthasarathi K.L. and Ranganathan S., 2000. Aging effect on enzyme activities in pressmud vermicasts of Lampito mauritii (Kinberg) and Eudrilus eugeniae (Kinberg). Biol. Fertil. Soils, 30(4), 347-350, https://doi.org/10.1007/s003740050014

Plaza C., Hernández D., García-Gil J.C., and Polo A., 2004. Microbial activity in pig slurry-amended soils under semiarid conditions. Soil Biol. Biochem., 36(10), 1577-1585, https://doi.org/10.1016/j.soilbio.2004.07.017

Samuel A.D., Domuta C., and Sandor M., 2008. Influence of longterm tillage, crop rotation and fertilisation combinations on soil enzyme activities. Int. J. Antimicrob. Agents, 12(1), 67-70.

Sharma S., Singh P., and Kumar S., 2020. Responses of soil carbon pools, enzymatic activity and crop yields to nitrogen and straw incorporation in a rice-wheat cropping system in north-western India. Front. Sustain. Food Syst., 4, 532704, https://doi.org/10.3389/fsufs.2020.532704 
Shi S.H., Tian L., Nasir F., Bahadur A., Batool A., Luo S.S., Yang F., Wang Z.C., and Tian C.J., 2019. Response of microbial communities and enzyme activities to amendments in saline-alkaline soils. Appl. Soil Ecol., 135, 16-24, https://doi.org/10.1016/j.apsoil.2018.11.003

Singh K., Trivedi P., Singh G., Singh B., and Patra D.D., 2016. Effect of different leaf litters on carbon, nitrogen and microbial activities of sodic soils. Land Degrad. Dev., 1215-1226, https://doi.org/10.1002/ldr.2313

Tripathy R. and Singh A.K., 2004. Effect of water and nitrogen management on aggregate size and carbon enrichment of soil in rice-wheat cropping system. J. Plant Nutr. Soil Sc., 167, 216-228, https://doi.org/10.1002/jpln.200321175

Wang J., Zhang L., Pang H., and Zhang J., 2017. Returning granulated straw for accelerating decomposition rate and improving soil fertility. Transactions of the CSAE, 33(6), 177-183.

Wang Y., Gong J., Li J., Xin Y., Hao Z., Chen C., Li H., Wang B., Ding M., Li W., Zhang Z., Xu P., Xu T., Ding G., and Li J., 2020. Insights into bacterial diversity in compost: Core microbiome and prevalence of potential pathogenic bacteria. Sci. Total. Environ., 718, 137304, https://doi.org/10.1016/j. scitotenv.2020.137304

Wei S.H., Wang S.S., Zhou Q.X., Zhan J., Ma L.H., Wu Z.J., Sun T.H., and Prasad M.N.V., 2010. Potential of Taraxacum mongolicum Hand-Mazz for accelerating phytoextraction of cadmium in combination with eco-friendly amendments. J. Hazard. Mater., 181(1-3), 480-484, https:// doi.org/10.1016/j.jhazmat.2010.05.038

Wei T., Zhang P., Wang K., Ding R., Yang B., Nie J., Jia Z., and Han Q., 2015. Effects of wheat straw incorporation on the availability of soil nutrients and enzyme activities in semiarid areas. PLoS ONE, 10, e0120994, https://doi. org/10.1371/journal.pone.0120994

Wu H.H., Xu X.K., Duan C.T., Li T.S., and Cheng W.G., 2017. Effect of carbon and nitrogen addition on nitrous oxide and carbon dioxide fluxes from thawing forest soils. Int. Agrophys., 31, 339-349, https://doi.org/10.1515/intag-2016-0065

Yan Q., Xu Y., Yu Y., Zhu Z., and Feng G., 2018. Effects of Pharmaceuticals on microbial communities and activity of soil enzymes in mesocosm-scale constructed wetlands. Chemosphere, 212 (Dec.), 245-253, https://doi.org/10.1016/j. chemosphere.2018.08.059

Yu H.Y., Ding W.X., Luo J.F., Donnison A., and Zhang J.B., 2012. Long-term effect of compost and inorganic fertilizer on activities of carbon-cycle enzymes in aggregates of an intensively cultivated sandy loam. Soil Use Manag., 28(3), 347-360, https://doi.org/10.1111/j.1475-2743.2012.00415.x
Zhang C., Liu G., Xue S., and Song Z., 2011. Rhizosphere soil microbial activity under different vegetation types on the Loess plateau, China. Geoderma, 161, 115-125, https://doi. org/10.1016/j.geoderma.2010.12.003

Zhang H., Zeng Q., An S., Dong Y., and Darboux F., 2016. Soil carbon fractions and enzyme activities under different vegetation types on the Loess Plateau of China. Solid Earth Discuss., 1-27, https://doi.org/10.5194/se-2016-137

Zhang L., Chen X., Xu Y., Jin M., Ye X., Gao H., Chu W., Mao J., and Thompson M.L., 2020. Soil labile organic carbon fractions and soil enzyme activities after 10 years of continuous fertilization and wheat residue incorporation. Sci. Rep., 10(1), 1-10, https://doi.org/10.1038/s41598-020-68163-3

Zhang P., Chen X.L., Wei T., Yang Z., Jia Z.K., Yang B.P., Han Q.F., and Ren X.L., 2016. Effects of straw incorporation on the soil nutrient contents, enzyme activities, and crop yield in a semiarid region of China. Soil Tillage Res., 160, 65-72, https://doi.org/10.1016/j.still.2016.02.006

Zhang W.M., Yu C.X., Wang X.J., and Hai L., 2020. Increased abundance of nitrogen transforming bacteria by higher $\mathrm{C} / \mathrm{N}$ ratio reduces the total losses of $\mathrm{N}$ and $\mathrm{C}$ in chicken manure and corn stover mix composting. Bioresour. Technol., 297, 122410, https://doi.org/10.1016/j.biortech.2019.122410

Zhang X., Dong W., Dai X., Schaeffer S., Yang F., Radosevich M., Xu L., Liu X., and Sun X., 2015. Responses of absolute and specific soil enzyme activities to long term additions of organic and mineral fertilizer. Sci. Total Environ., 536, 5967, https://doi.org/10.1016/j.scitotenv.2015.07.043

Zhao S., Li K., Zhou W., Qiu S., Huang S., and He P., 2016. Changes in soil microbial community, enzyme activities and organic matter fractions under long-term straw return in north-central China. Agric. Ecosyst. Environ., 216, 82-88, https://doi.org/10.1016/j.agee.2015.09.028

Zhou D.Q., 1993. Microbiological tutorial. Beijing: Higher Education Press, 281-282.

Zhu H., Wu J., Huang D., Zhu Q., Liu S., Su Y., Wei W., Syers J.K., and Li Y., 2010. Improving fertility and productivity of a highly-weathered upland soil in subtropical China by incorporating rice straw. Plant Soil, 331, 427-437, https://doi. org/10.1007/s11104-009-0263-Z

Zimmerman A., 2010. Abiotic and microbial oxidation of laboratory-produced black carbon (biochar). Environ. Sci. Technol., 44(4), 1295-1301, https://doi.org/10.1021/es903140c 